\title{
Penyuluhan Pentingnya Pencegahan Penyakit Diabetes Sejak Dini Kepada Guru Perempuan TK Yaa Bunaaya I Gampong Ujong Drien
}

\author{
Fitrah Reynaldi ${ }^{1 *}$, Yarmaliza ${ }^{1}$, Teungku Nih Farisni ${ }^{1}$, Fitriani $^{1}$, Zakiyuddin $^{1}$ \\ ${ }^{1}$ Fakultas Kesehatan Masyarakat, \\ Universitas Teuku Umar \\ Penulis Korespondensi, Fitrah Reynaldi, Jurusan Ilmu Kesehatan Masyarakat, Universitas Teuku \\ Umar Email: fitrahreynaldi@utu.ac.id
}

\begin{abstract}
ABSTRAK
Diabetes merupakan penyakit tidak menular yang masih menjadi penyebab kematian atau kecacatan bagi masyarakat Aceh. Gaya hidup, pola makan serta olah raga teratur harus dibudayakan sejak dini karena perubahan perilaku membutuhkan waktu yang sangat lama. Guru perempuan TK Yaa Bunaaya I merupakan corong yang sangat strategis untuk menanamkan upaya perubahan perilaku sejak dini bagi anak- anak. Kegiatan penyuluhan ini menghadirkan seluruh guru perempuan TK Yaa Bunaaya I sebagai peserta untuk nantinya dapat terlibat langsung dalam menanamkan pondasi perilaku hidup sehat bagi peserta didik. Tujuan kegiatan pengabdian ini untuk memberikan pemahaman kepada guru tentang pola perilaku pencegahan penyakit diabetes sedini mungkin. Pengabdian ini telah dilaksanakan pada tanggal 28 Desember 2019 dengan metode edukasi berupa penyuluhan kepada guru perempuan TK Yaa Bunaaya I. Adapun hasil dari edukasi ini adalah adanya peningkatan pengetahuan guru terhadap pentingnya pencegahan penyakit diabetes melalui penanaman perilaku hidup sehat sejak dini.
\end{abstract}

Kata Kunci: Penyuluhan, Diabetes, Guru Perempuan

\section{Abstract}

Diabetes is a non-communicable disease that is still the cause of death or disability for the people of Aceh. Lifestyle, diet and regular exercise must be cultivated from an early age because behavior change takes a very long time. Kindergarten female teachers are very strategic funnels for inculcating early behavior change efforts for children. This outreach activity presents all kindergarten female teachers as participants to later be directly involved in instilling the foundations of healthy living behaviors for students. The purpose of this service activity is to provide teachers with an understanding of diabetes prevention behavior patterns as early as possible. This service was carried out on December 28, 2019 with an educational method in the form of counseling to Yaa Bunaaya I Kindergarten female teachers. The result of this education was an increase in teachers' knowledge of the importance of preventing diabetes through planting healthy habits from an early age.

Keywords: Counseling, Diabetes, Female Teacher

\section{PENDAHULUAN}

\section{Analisis Situasi}

Diabetes adalah penyakit tidak menular yang masih menjadi penyebab kematian atau kecacatan bagi masyarakat Aceh. Gaya hidup, pola makan serta olah raga teratur harus dibudayakan sejak dini karena perubahan perilaku membutuhkan waktu yang sangat lama. Guru perempuan TK Yaa Bunaaya I merupakan tokoh yang sangat penting untuk menanamkan upaya perubahan perilaku sejak dini bagi anak- anak usia sekolah TK. Guru merupakan orang tua kedua bagi anak- anak. Perkataan dan perilaku seorang guru adalah yang paling bisa mengubah perilaku pada anak- anak terutama anak usia dini.

Tak bisa dipungkiri, orang Indonesia sangat menggemari makanan manis. Data Badan Penelitian dan Pengembangan Kesehatan Kementerian Kesehatan Republik Indonesia menunjukkan bahwa $4,8 \%$ penduduk Indonesia mengonsumsi lebih dari 50 gram gula per orang per hari (Balitbangkes, 2020). 
Berdasarkan jenis kelamin $6,4 \%$ pria dan $3,6 \%$ wanita mengudap makanan manis lebih dari standar kesehatan. Makanan manis yang paling banyak dikonsumsi orang Indonesia yaitu gula pasir $(13,6 \%))$, permen dan cokelat $(2,8 \%)$ serta sirop $(1,2 \%)$. Padahal jika dikonsumsi secara berlebihan makanan manis dapat berisiko buruk bagi kesehatan (Balitbangkes, 2020 ).

Diabetes atau yang akrab disebut kencing manis adalah suatu kondisi dimana tubuh penderitanya tidak mampu mengontrol kadar gula (glukosa) dalam tubuhnya. Diabetes juga mengakibatkan tubuh tidak dapat menghasilkan hormon insulin (hormon untuk mengatur gula darah) yang dibutuhkan sehingga ketika kita memeriksakan diri ke dokter kadar gula sudah melonjak tinggi karena insulin tidak bisa menjalankan peranannya dengan optimal (Sjarif, 2011).

Diabetes Melitus saat ini menjadi masalah kesehatan yang serius di dunia selain penyakit jantung, termasuk Indonesia. Indonesia merupakan negara yang ada di urutan ke-4 dengan prevelansi diabetes tertinggi di dunia setelah India, Republik Rakyat Cina dan negara adidaya Amerika Serikat. Hasil penelitian Organisasi Kesehatan Dunia (WHO) menunjukkan jumlah penderita diabetes terus mengalami peningkatan dari tahun ke tahun, terutama Diabetes tipe 2. Bahkan WHO memperkirakan jumlah pengidap kencing manis di Indonesia akan melonjak hingga 21,3 juta jiwa pada tahun 2030 mendatang (Matthew, 2016).

Fakta yang terpapar diatas terdengar mengerikan, namun bukan berarti tidak mungkin untuk dicegah sejak dini. Lebih baik mencegah daripada mengobati bukan sekedar pernyataan retoris belaka, semua penyakit apapun itu dapat lebih mudah diobati jika kita sadar akan gejalanya dari awal sehingga pengobatan akan lebih mudah dan cepat berjalan. Namun sayangnya, ternyata $60 \%$ masyarakat Indonesia kerap tidak menyadari bahwa dirinya telah terkena penyakit diabetes.
Mayoritas baru memeriksakan diri ke dokter ketika sudah terjadi komplikasi dalam tubuhnya. Hal ini menunjukkan kesadaran akan bahaya penyakit diabetesyang masih rendah, terutama kalangan awam (CDC, 2011).

Diabetes dapat dialami oleh semua orang. Tapi diperlukan perhatian utama untuk seseorang yang memiliki riwayat Diabetes dalam keluarga. Selain riwayat keluarga, faktor risiko lainnya adalah mereka yang mempunyai berat badan berlebih (obesitas), kolesterol tinggi (disebabkan pola makan yang tidak baik), Hipertensi dan kurang aktifitas fisik. Mereka yang telah menginjak usia lebih dari 40 tahun disertai dengan kegemukan akan semakin berisiko untuk terkena penyakit Diabetes (CDC, 2011).

Menurut Centers for Disease Control and Prevention (CDC) 2011, ada beberapa cara yang sebenarnya dapat diterapkan untuk mencegah datangnya diabetes bertamu dalam hidup kita, antara lain: Mengetahui penyebab Diabetes. Rajin melakukan riset mengenai apa saja penyebab diabetes, faktor pemicu dan gejala yang mengarah pada penyakit diabetes adalah solusi awal untuk mengantisipasi dari jauh hari. Tidak ada salahnya untuk mengadopsi gaya hidup sehat sejak masih berusia muda, tidak perlu menunggu hingga usia lanjut dan adanya penyakit menghampiri.

Kurangi makanan yang berlemak. Lebih baik mengontrol diri daripada menyesal di kemudian hari benar adanya. Makanan berlemak merupakan makanan utama yang mengakibatkan tingginya kadar glukosa dalam tubuh. Oleh karena itu ada baiknya tidak terlalu sering makan junk food dan makanan yang tidak dibuat dari bahanbahan yang sehat jadi risiko terkena diabetes dapat diminimalisir. Kurangi makanan dan minuman manis. Mungkin tergolong sulit mengingat ketergantungan masyarakat Indonesia terhadap sesuatu yang manis cukup tinggi. Namun makanan manis inilah yang dapat menimbun zat gula dalam tubuh 
Jurnal Perempuan dan Anak Indonesia

yang kedepannya mengungang penyakit kencing manis. Belajarlah mengurangi makan kue yang mengandung gula tinggi dan minuman manis dengan pemanis buatan yang tak sehat untuk tubuh.

Kurangi porsi makan. Pernah mendengar premis, berhentilah makan sebelum kenyang? Dengan kata lain, jangan memakan segala sesuatu secara berlebihan. Lemak yang nantinya menumpuk akan menyebabkan kelebihan berat badan (obesitas) yang meningkatkan risiko terkena diabetes. Rajin berolahraga. Karena dengan rutin berolahraga minimal 20 menit per hari akan membantu menurunkan kadar gula dalam tubuh serta meningkatkan sensitivitas hormon insulin. Tidak perlu melakukan olahraga berat, jalan-jalan ringan pada pagi hari dan bersepeda di akhir pekan sudah cukup membakar kalori dalam tubuh jika dilakukan secara konsisten. Utamakan makan sayur mayur. Sayuran terbaik untuk seseorang yang menderita diabetes ialah bayam, brokoli, kale dan selada. Sayuran mengandung rendah kalori sehingga tidak akan berakibat kegemukan jika rutin dikonsumsi.

Jauhi stres. mustahil memang manusia terhindar dari stres apalagi jika mengalami suatu masalah dalam kehidupan. Namun stres yang berlebihan dan sering tidak baik untuk kesehatan. Rajinlah melakukan aktivitas favorit dan berlibur untuk menghindari kadar stres yang melebihi batas.

Istirahat cukup dan teratur. Dengan beristirahat selama 8 jam sehari sudah membantu memproduksi hormon insulin secara optimal untuk memecah kadar gula dalam tubuh Rutin sarapan di pagi hari. Sejujurnya penulis senyum miris ketika nulis poin yang ini. Karena penulis adalah golongan yang termasuk jarang malah nyaris gak pernah sarapan. Tetapi penulis akan bertekad mengubah pola yang selama ini bertahan, karena orang yang rutin sarapan memiliki kadar gula darah yang rendah jadi penyakit diabetes dapat dicegah dini. Jadi yang masih malas sarapan, yuk sarapan mulai besok untuk mencegah penyakit diabetes dekat-dekat sama kita.

Berdasarkan uraian diatas maka kegiatan dalam bentuk pengabdian masyarakat ini bekerjasama dengan aparat desa dan masyarakat gampong Ujong Drien Kecamatan Meureubo Kab. Aceh Barat dianggap dapat memberi peningkatan pengetahuan dan pemahaman, sehingga diharapkan guru perempuan TK Ya Bunaaya I akan menanamkan pola hidup sehat kepada anak- anak usia dini.

\section{Tujuan dan Manfaat Kegiatan}

Kegiatan pengabdian ini bertujuan untuk peningkatan pemahaman Guru perempuan TK Ya Bunaaya I terhadap pentingnya pencegahan penyakit diabetes sejak dini, maka luaran yang dihasilkan atau ditargetkan dalam kegiatan pengabdian adalah peningkatan pengetahuan dan pemahaman Guru perempuan TK yaa Bunaaya I terhadap pentingnya pencegahan penyakit diabetes sejak dini kepada murid TK Yaa Bunaaya I sehingga diharapkan para Guru akan menanamkan pola hidup sehat kepada anak didiknya.

\section{METODE PELAKSANAAN}

\section{Sasaran Kegiatan}

Sasaran kegiatan ini adalah Guru perempuan TK Yaa Bunaaya I Gampong Ujong Drien Kecamatan Meureubo Kabupaten Aceh Barat

\section{Lokasi Kegiatan}

Pengabdian ini dilaksanakan di Ruang Serbaguna TK Yaa Bunaaya I Gampong Ujong Drien Kecamatan Meureubo Kabupaten Aceh Barat.

\section{Metode Pelaksanaan}


Metode pelaksanaan yang di gunakan adalah edukasi melalui penyuluhan untuk peningkatan pemahaman guru perempuan TK Ya Bunaaya I tentang pentingnya pencegahan diabetes sejak dini (Gambar 1). Pelaksanaan kegiatan ini memiliki beberapa tahapan, yaitu tahapan persiapan tim, diskusi edukasi dengan guru, dilanjutkan pada tahapan diskusi dan tanya jawab terkait dengan pentingnya pencegahan penyakit diabetes sejak dini.

Untuk mempermudah dalam kegiatan pengabdian ini, maka penulis membuat alur kegiatan seperti pada Bagan berikut:
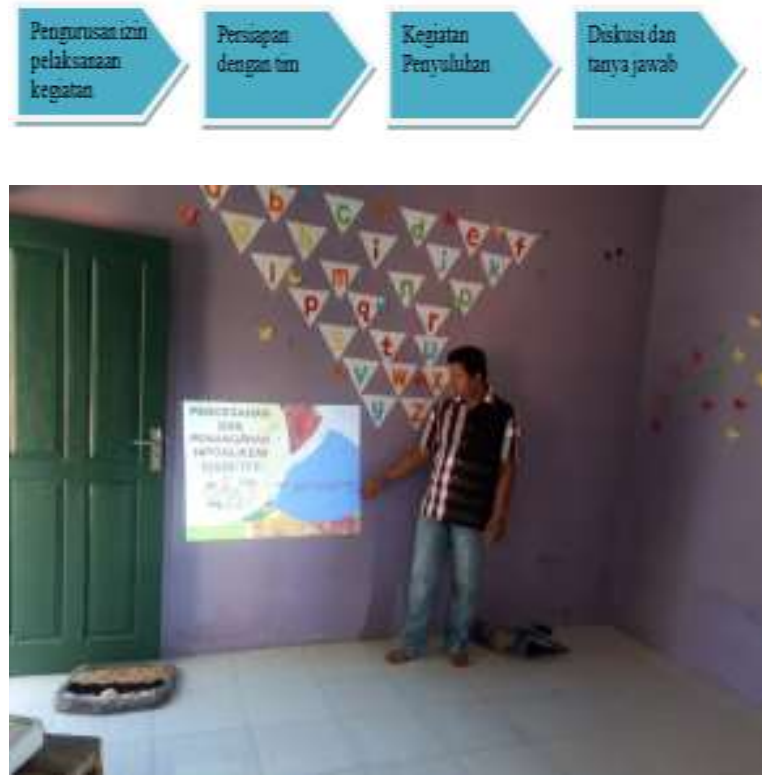

Gambar 1. Kegiatan Penyuluhan yang dihadiri oleh seluruh guru perempuan TK Yaa Bunaaya I

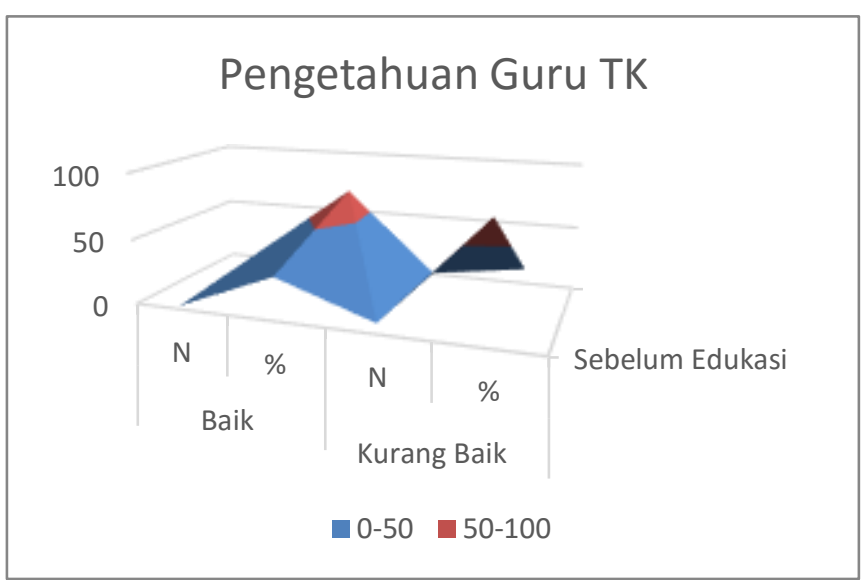

Gambar 3. Grafik hasil kegiatan guru TK sebelum dan setelah dan kegiatan penyuluhan
Materi yang diberikan pada penyuluhan ini antara lain: Definisi diabetes mellitus, klasifikasi diabetes mellitus, tanda dan gejala, serta materi tentang pencegahan penyakit diabetes mellitus. Kegiatan pengabdian ini dilakukan dengan melibatkan mahasiswa Fakultas Kesehatan Masyarakat Universitas Teuku Umar.

\section{HASIL KEGIATAN DAN PEMBAHASAN}

Pengabdian kepada masyarakat dengan judul penyuluhan pentingnya pencegahan penyakit diabetes sejak dini kepada Guru perempuan TK Yaa Bunayaa I Gampong Ujong Drien Kecamatan Meureubo Kabupaten Aceh Barat (Gambar 2)

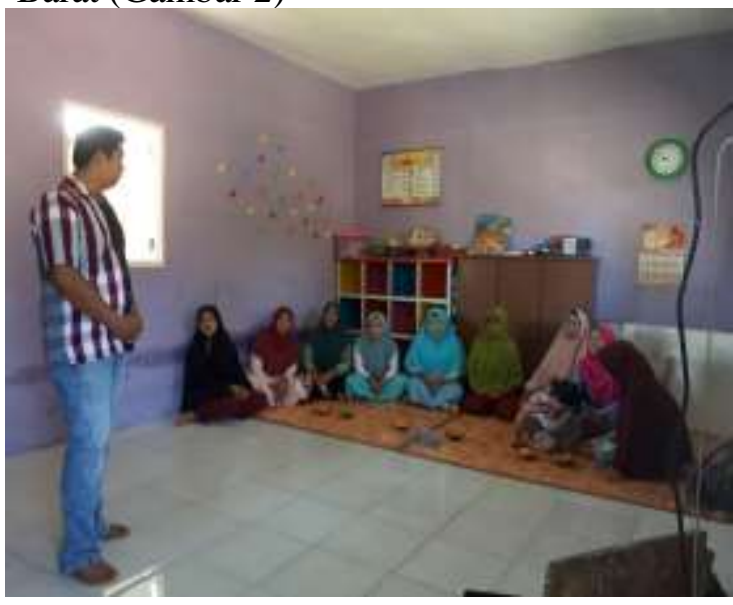

Gambar 2. Diskusi dan tanya jawab dengan seluruh guru perempuan TK Yaa Bunaaya I

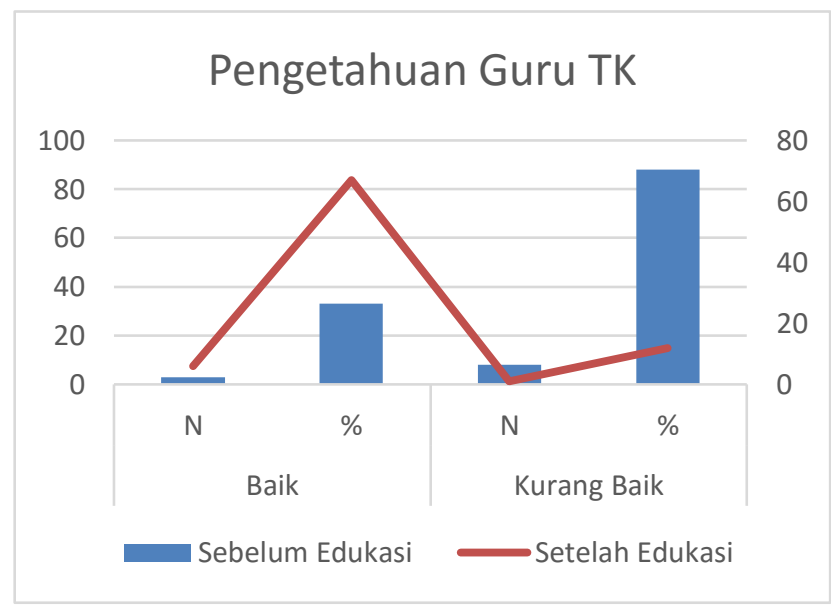

Gambar 4. Perubahan pengetahuan guru TK sebelum dan setelah dan kegiatan penyuluhan 
Berdasarkan Gambar 3 menunjukkan bahwa pengetahuan guru TK yang kurang baik sebelum diberikan edukasi sebanyak 8 orang atau $88 \%$, sedangkan guru TK yang berpengetahuan baik sebelum di edukasi hanya 1 orang atau $12 \%$ pada Gambar 4 juga dapat dilihat bahwa pengetahuan guru meningkat setelah di berikan penyuluhan terkait pentingnya pencegahan penyakit diabetes sejak dini. Gambar 4 menunjukkan bahwa pengetahuan guru TK baik setelah diberikan penyuluhan sebanyak 6 orang guru atau sekitar $67 \%$, sedangkan pengetahuan guru TK yang kurang baik hanya 3 orang atau $33 \%$ orang.

Sekolah merupakan salah satu pihak yang turut berperan penting dalam memberikan pendidikan kesehatan bagi anak yang bertujuan untuk menanamkan kebiasaan hidup sehat bagi anak (Depkes RI, 2003). Guru memiliki pengaruh dalam hal pemilihan makanan selama anak berada di sekolah. Guru juga dapat memberi pendidikan kesehatan tentang gizi, dan menjadi role model dalam perilaku gizi sehat. Selain peran guru dan asupan makan, aktivitas fisik yang dilakukan selama di sekolah dan waktu luang juga dapat menjadi salah satu faktor yang berperan dalam kejadian obesitas pada anak usia sekolah (Langford R, 2015).

\section{KESIMPULAN DAN SARAN}

Kegiatan penyuluhan tentang pencegahan diabetes sejak dini telah dilaksanakan tepat waktu dan berjalan dengan baik. Disaat pelaksanaan penyuluhan, peserta memberikan respon yang positif dan berperan aktif dengan melakukan tanya jawab dan diskusi mengenai permasalahan yang berkaitan dengan upaya pencegahan penyakit diabetes sejak dini. Diharapkan peran aktif guru perempuan TK Yaa Bunaaya I dalam menerapkan pola perilaku hidup sehat sejak dini dengan metode-metode yang ramah untuk anak usia taman kanak- kanak.

\section{DAFTAR PUSTAKA}

Bina Kesehatan Anak. Pedoman Akselerasi Pembinaan dan Pelaksanaan UKS. Bina Kesehatan Anak, Depkes RI. 2003. 1-50 p.

Centers for Disease Control and Prevention (CDC). 2011. School Health Guidelines to Promote Healthy Eating and Physical Activity. Morbidity and Mortality Weekly Report, 60(5).

Langford R, Bonell C, Jones H, Campbell R. Obesity prevention and the Health promoting Schools framework: essential components and barriers to success. Int $\mathrm{J}$ Behav Nutr Phys Act [Internet]. 2015;12(1):15. Available from: http://www.ijbnpa.org/content/12/1/ 15

Matthew AK, Monintja TCN, Ratag GAE. Sikap guru mengenai intervensi diet dan aktivitas fisik pada siswa obesitas di sekolah dasar. J Kedokt Komunitas Dan Trop. 2016;IV(1):1-8.

Sjarif Dr, Lestari Ed, Mexitalia M, Nasar Ss. Buku Ajar Nutrisi Pediatrik Dan Penyakit Metabolik. Jilid I. Jakarta: Ikatan Dokter Anak Indonesia; 2011 